\title{
Influence of Slope Aspect on Plant Community Composition and its Implications for Restoration of a Chinese Mountain Range
}

\author{
Qin Yanyan $^{1-3}$, Nicholas Holden ${ }^{4}$, Feng Qi ${ }^{1 *}$, Zhu Meng ${ }^{1,3}$ \\ ${ }^{1}$ Key Laboratory of Ecohydrology of Inland River Basin, Alashan Desert Ecohydrology Research Station, Northwest \\ Institute of Eco-Environment and Resources, Chinese Academy of Sciences Lanzhou 730000, China \\ ${ }^{2}$ Research Institute of Forestry Science of Bai Long Jiang Forestry Management Bureau, Lanzhou, China \\ ${ }^{3}$ University of the Chinese Academy of Sciences, Beijing 100039, China \\ ${ }^{4}$ UCD School of Biosystems Engineering, Agriculture and Food Science Centre, University College Dublin, \\ Belfield, Dublin 4, Ireland
}

Received: 13 May 2016

Accepted: 2 August 2016

\begin{abstract}
Excessive human disturbance (e.g., overgrazing, deforestation) has degraded the environment in the Qilian Mountains in China. Vegetative restoration is likely to be a crucial tool to restore these biologically significant habitats, but it is impossible to achieve this goal if the baseline plant community composition and its variation with local environmental conditions were not understood fully. To assess plant community composition by slope aspect, four different aspects - south-facing slope (SF), southwest-facing slope (SW), northwest-facing slope (NW), and north-facing slope (NF) - were surveyed on three almost non-degraded mountains. The results showed that each slope aspect has different abiotic environments. From SF to NF, soil water content has an increasing trend, but it shows no difference between SF and SW; and daily soil temperature and $\mathrm{pH}$ have a decreasing trend, while the former shows no difference between SF and SW, and SW and NW; and the latter shows no difference between SW and NW; and soil organic carbon was significantly increased, but soil bulk density was significantly decreased. Herbaceous plants were dominant on SF, SW, and NW, and trees (Picea crassifolia) were dominant on NF. From SF to NW, the dominant herbaceous plants were Agropyron cristatum and Stipa grandis, Agropyron cristatum and Carex aridula, and Kobresia humilis and Carex crebra, respectively, while on NF they were Carex spp. and Polygonum macrophyllum. The baseline survey points to the need to consider underlying patterns in abiotic conditions when planning restoration programs in these degraded mountain habitats, and to select native plants similar to the original vegetation. The survey provides a vital milestone for the development of policy-based funding initiatives and for ongoing vegetation monitoring during restoration to assess if these vegetative targets have been met.
\end{abstract}

Keywords: degradation, dominant species, ecological restoration, Qilian Mountains

*e-mail: qifeng@1zb.ac.cn 


\section{Introduction}

The combined effects of deforestation, overgrazing, expansion of cropland, and the unsustainable use of natural resources have caused land degradation worldwide, leading to powerful influence on the structure and function of ecosystems [1-2]. This type of degradation has occurred in the Qilian Mountains, which are the headwaters of the Heihe River Basin in China [3-5]. It has lead to serious environmental issues mainly due to lack of vegetative cover and strong erosive forces [6], especially for the important carbon pools of forest and grassland [7-9], which have the potential to mitigate the impacts of climate change [10-14]. When vegetation was diagnosed as being at risk and ecosystems were degraded by human activities, the recovery process should be implemented as soon as possible [15-16]. Apart from the construction of physical barriers, vegetation restoration provides a powerful tool for site rehabilitation [16].

The first step in the restoration process is to select native plants that are similar to the original vegetation [17-19]. Native plant species, which become fine-tuned to their local environments through natural selection, can rapidly recolonize a denuded landscape [20-22] and help maintain the diversity and stability of vegetative communities [5], suppress weeds and reduce erosion [23], and increase nutrient concentrations ( $\mathrm{P}, \mathrm{N}, \mathrm{K})$ and rain/water use efficiency, of which the latter is a main indicator for ecosystem productivity [24-25]. The use of native plant species during rehabilitation will also contribute to the aesthetic value of the habitat, as well as benefiting belowground ecosystems [26], minimizing resource depletion [27], ameliorating the consequences of fragmentation on populations of valuable plant species [28], attracting more visitors on flower [29], and increasing the abundance of small mammals as well as carnivorous prey selection species [30]. The ability to know regarding a species' native status according to appropriate environmental baselines is of vital importance for current-day environmental management [31].

In general, for mountain environments slope aspect plays a key role in regulating insolation, which in turn affects soil moisture and temperature regimes in ways that can directly influence the development of local vegetation and ecosystems [32-35]. Slope aspect influences almost all properties of vegetation, such as species composition and distribution, plant performance and photosynthetic efficiency, cover and productivity, species diversity and functional diversity, plant invasion, leaf ${ }^{\delta 13} \mathrm{C}$, distribution of $\mathrm{C}_{3}$ and $\mathrm{C}_{4}$ plants, and nutrient dynamics [6, 33, 36-42]. It may also affect plant species establishment through sensitivity to temperature and climatic fitness [43-44], and the hydrological precipitation pattern and erosion $[6$, 45]. An understanding of the differences in vegetation and soil characteristics among slope aspects in high-altitude environments is fundamentally important for efficient management of these mountains [46]. Therefore, prior to re-establishing an ecosystem that is most like the original ecosystem of degraded mountains, the composition of vegetative communities on lightly disturbed sites must be investigated thoroughly to establish a baseline. Changes in vegetation composition are very common in land degradation, such as in parts of South Africa [36], on the Qinghai-Tibetan Plateau [47, 48], and in Syrian arid steppes [49].

For example, Louhaichi et al. [49] found that the similarity index between degraded and protected sites was estimated at $45 \%$, which indicates that there is considerable difference in plant composition. Also, the relative abundance and density of species and interrelationships with changes in slope aspect should be measured because the restoration process is affected by both biotic and abiotic conditions, and the only production of a species list is inadequate and will likely be reflected in low species survival rates [50-54]. The objective of this work was to undertake and interpret a baseline survey of vegetation and soil properties in the Qilian Mountains to establish species composition and their relationship with abiotic factors.

\section{Material and Methods}

The Qilian Mountains are located in the northeastern part of the Qinghai-Tibet Plateau in China. They have a northwest-southeast trend and are composed of a series of parallel mountain chains and broad valleys. With the geographical boundary of about $93.4^{\circ}-103.4^{\circ} \mathrm{E}$ and $35.8^{\circ}-40.0^{\circ} \mathrm{N}$, the Qilians have a total area of about $19.5 \times 10^{4} \mathrm{~km}^{2}$. The lower section of the mountains mainly distribute arid geomorphology; the middle section fluvial geomorphology; and the high section permafrost geomorphology [55]. This area characteristically has a humid cold climate with an elevation varying between 2,000 and 5,500 m, and a mean annual precipitation from 250 to $500 \mathrm{~mm}$. The highest air temperature in summer can reach about $40^{\circ} \mathrm{C}$ in the plains and downstream area, while the lowest air temperature in winter falls to about $-40^{\circ} \mathrm{C}$ in the high mountain upper basin area, and the average temperature is $0.5^{\circ} \mathrm{C}$. The upper reaches of the Heihe River flow out of the Qilian Mountains, which represent the water source of the Heihe, which in turn provides water for agricultural production and ecosystem stabilization in the middle and lower reaches of the Basin $[3,56-57]$.

The survey site, named Da Yekou Basin (100 $13^{\prime}-$ $\left.100^{\circ} 16^{\prime} \mathrm{E}, 38^{\circ} 16^{\prime}-38^{\circ} 33^{\prime} \mathrm{N}\right)$, was located in the middle of the Qilian Mountains, with an elevation varying between 2,600 and 4,645 $\mathrm{m}$. This site has a mean annual precipitation of about $435.5 \mathrm{~mm}$, and an average temperature of $5.4^{\circ} \mathrm{C}$. The local residents stated that both human and natural processes have only lightly disturbed the vegetation over the last 60 years, a finding confirmed by Zhang [58]. In his study, Zhang [58] found that Picea crassifolia of this area was between 52 and 117 years old so the vegetation can be regarded as a climax community. Generally, native plants in a climax community have the greatest chance of growth and survival under the prevailing conditions, and 
the success of restoration depends on a general knowledge of them [59].

During July and September 2013 and 2014, around an elevation of about $2,900 \mathrm{~m}$, four slope aspects of three mountains were selected for analysis. On each mountain, four slope aspects were chosen: south- (SF, $\left.0^{\circ}-90^{\circ}\right)$, southwest- (SW, $\left.90^{\circ}-135^{\circ}\right)$, northwest- (NW, $\left.135^{\circ}-225^{\circ}\right)$ and north-facing slopes (NF, $180^{\circ}-270^{\circ}$ ) (Fig 1). As the vegetation differed in these areas the floral sampling regime differed according to best practices for individual habitat types. In grassland areas a sample comprised of three plots $10 \mathrm{~m}$ apart. In each plot, three $50 \mathrm{~cm} \times 50 \mathrm{~cm}$ quadrats were established in a row $1 \mathrm{~m}$ apart (Fig. 1). Within each of these quadrats, percentage cover and the number of individuals of each species was recorded. In woody land a grid of three plots were used to sample the tree communities. Spaced $10 \mathrm{~m}$ apart, three $10 \mathrm{~m} \times 10$ $\mathrm{m}$ quadrats were established in a row within which trees with a diameter at breast height of $\geq 5 \mathrm{~cm}$ were defined as individuals. Within each quadrat we recorded canopy density, number of living trees, number of felled trees, canopy, and diameter at breast height. Five $1 \mathrm{~m} \times 1 \mathrm{~m}$ herbaceous quadrats were also established in each of the tree quadrats (four in the corners and one in the center). Plant communities in these quadrats were assessed as described above. At the same time, three grassland quadrate and five tree quadrate soil samples were taken at a depth of $60 \mathrm{~cm}$ and divided into four parts $(0-10 \mathrm{~cm}$, $10-20 \mathrm{~cm}, 20-40 \mathrm{~cm}$, and 40-60 cm depths) as replicates in each quadrat on a sunny day. In our surveyed sites, only a few but very small shrubs were found on NF of one mountain, so we excluded them in analysis.

Diameters at breast height were measured with calipers, while crown projection was recorded as two perpendicular diameters checked with a tape measure. Soil daily temperature was monitored from 06:00 to 18:00 at one-hour intervals $10 \mathrm{~cm}$ belowground using an EM50 soil temperature datalogger (Decagon Devices Inc, USA) by inserting its probes into three random locations on each aspect during investigation [41]. The fresh mass of soil was

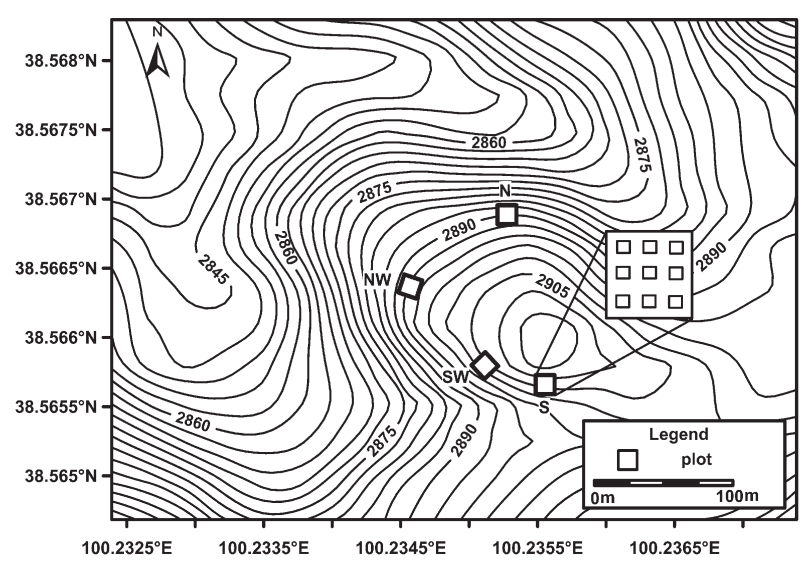

Fig. 1. Slope aspect selected and plot designed. (SF: south-facing slope, SW: southwest slope, NW: northwest slope, NF: northfacing slope). dried in an oven at $105^{\circ} \mathrm{C}$ for $48 \mathrm{~h}$. Soil water content was measured as $\left(\operatorname{mass}_{f}-\right.$ mass $\left._{d}\right) /$ mass $_{f} \times 100 \%$, where mass is $_{f}$ the fresh mass of soil and mass ${ }_{d}$ is the dry mass of soil. Soil bulk density was determined from the undisturbed core segments as dry soil mass per unit volume. Soil organic carbon (SOC) was determined by wet dichromate oxidation using a homogenized subsample of $0.2 \mathrm{~g}$ soil and titrated by $\mathrm{FeSO}_{4}$ [60]. pH was determined using a 2.5:1 water-to-soil ratio and standard $\mathrm{pH}$ meter [61].

An importance value index of herbaceous plants was calculated as: $\mathrm{I}_{i v}=\left(\mathrm{R}_{c}+\mathrm{R}_{f}+\mathrm{R}_{d}\right) / 3$, where $\mathrm{I}_{i v}$ is the importance value index, $\mathrm{R}_{c}$ is the relative cover, $\mathrm{R}_{f}$ is the relative frequency, and $\mathrm{R}_{d}$ is the relative density. Community similarity was expressed as $\mathrm{CS}=2 \mathrm{c} /(\mathrm{a}+\mathrm{b})$ [62], where c represents the common species of two slope aspects, and $a$ and $b$ represent the number of species on each slope aspect.

The data were analyzed using SPSS 16.0 statistical software. One-way analysis of variance was used to determine differences in the parameters involved in the study at a level of $\mathrm{p}<0.05$.

\section{Results and Discussion}

The mean (and standard deviation) of the abiotic conditions of the survey sites were presented in Table 1. SF and SW had the same soil type, which was different from NW and NF. Except for these two indicators, other indicators on NF were significantly different in other aspects, with the highest soil water content and SOC, and the lowest $\mathrm{pH}$, soil daily temperature, and soil bulk density. Except for no difference in soil daily temperature and soil-water content between SF and SW, these indicators on SF were different from SW and NW, with the highest $\mathrm{pH}$ and soil bulk density and the lowest SOC and soil water content. Except for soil daily temperature and $\mathrm{pH}$, SOC, soil water content, and soil bulk density between SW and NW were all significantly different. On all slope aspects, SOC significantly decreased with soil depth, and $\mathrm{pH}$ on NW and NF increased significantly with soil depth, but on SF and SW, pH value of the first soil layer was significantly lower than that of other layers, among which $\mathrm{pH}$ value was not different. Soil-water content on NF decreased significantly with soil depth, but it has no difference between 10-20 cm and 20-40 cm depth, while soil bulk density on NF has an inverse trend, increasing significantly with soil depth, except between the $10-20 \mathrm{~cm}$ and 20-40 cm layers. On SF, SW, and NW, among all soil depths, no differences of soil water content and soil bulk density were found.

Herbaceous plants made up the vegetation on SF, $\mathrm{SW}$, and NW, while on NF vegetation it was trees and herbaceous plants. On SF, Agropyron cristatum had the highest $\mathrm{I}_{i v}$, while on SW, NW, and NF, Carex aridula, Kobresia humilis, and Carex spp had the highest $\mathrm{I}_{i v}$, respectively. Plant community composition varied with slope aspect as did relative abundance. However, for other species the higher $\mathrm{I}_{i v}$ was not necessarily related 
Table 1. Abiotic conditions by each slope aspect.

\begin{tabular}{|c|c|c|c|c|}
\hline & SF & SW & NW & NF \\
\hline Slope $\left(^{\circ}\right)$ & 30 & 33 & 36 & 31 \\
\hline Soil type & $\begin{array}{l}\text { mountain } \\
\text { chestnut soil }\end{array}$ & $\begin{array}{c}\text { mountain } \\
\text { chestnut soil }\end{array}$ & $\begin{array}{l}\text { subalpine } \\
\text { meadow soil }\end{array}$ & $\begin{array}{c}\text { mountain grey } \\
\text { cinnamon forest soil }\end{array}$ \\
\hline $\operatorname{SDT}\left({ }^{\circ} \mathrm{C}\right)$ & $16.63( \pm 4.71) \mathrm{A}$ & $16.02( \pm 4.46) \mathrm{AB}$ & $14.40( \pm 2.80) \mathrm{B}$ & $7.43( \pm 0.46) \mathrm{C}$ \\
\hline \multicolumn{5}{|c|}{$\mathrm{pH}$} \\
\hline $0-10 \mathrm{~cm}$ & $8.13( \pm 0.17) b$ & $8.03( \pm 0.11) b$ & $8.00( \pm 0.10) d$ & $7.83( \pm 0.10) \mathrm{d}$ \\
\hline $10-20 \mathrm{~cm}$ & $8.29( \pm 0.24) \mathrm{a}$ & $8.22( \pm 0.18) \mathrm{a}$ & $8.07( \pm 0.11) \mathrm{c}$ & $8.00( \pm 0.10) \mathrm{c}$ \\
\hline $20-40 \mathrm{~cm}$ & $8.37( \pm 0.33) \mathrm{a}$ & $8.30( \pm 0.26) \mathrm{a}$ & $8.23( \pm 0.15) b$ & $8.11( \pm 0.10) b$ \\
\hline $40-60 \mathrm{~cm}$ & $8.35( \pm 0.26) \mathrm{a}$ & $8.22( \pm 0.26) \mathrm{a}$ & $8.32( \pm 0.12) \mathrm{a}$ & $8.20( \pm 0.10) \mathrm{a}$ \\
\hline Average & $8.29( \pm 0.27) \mathrm{A}$ & $8.19( \pm 0.23) \mathrm{B}$ & $8.17( \pm 0.17) \mathrm{B}$ & $8.04( \pm 0.10) \mathrm{C}$ \\
\hline \multicolumn{5}{|c|}{$\mathrm{SOC}(\mathrm{g} / \mathrm{kg})$} \\
\hline $0-10 \mathrm{~cm}$ & $24.49( \pm 7.02) \mathrm{a}$ & $29.42( \pm 6.63) \mathrm{a}$ & $49.27( \pm 11.33) \mathrm{a}$ & $100.14( \pm 25.03) \mathrm{a}$ \\
\hline $10-20 \mathrm{~cm}$ & $18.61( \pm 5.21) b$ & $23.67( \pm 5.41) b$ & $34.32( \pm 8.41) b$ & $77.05( \pm 15.68) \mathrm{b}$ \\
\hline $20-40 \mathrm{~cm}$ & $12.95( \pm 4.32) \mathrm{c}$ & $17.30( \pm 2.31) \mathrm{c}$ & $28.08( \pm 6.94) \mathrm{c}$ & $64.51( \pm 18.59) \mathrm{c}$ \\
\hline $40-60 \mathrm{~cm}$ & $8.59( \pm 3.66) \mathrm{d}$ & $12.08( \pm 3.02) \mathrm{d}$ & $22.16( \pm 7.63) \mathrm{d}$ & $44.81( \pm 18.65) \mathrm{d}$ \\
\hline Average & $16.16( \pm 7.9) \mathrm{D}$ & $20.63( \pm 4.90) \mathrm{B}$ & $33.46( \pm 13) \mathrm{C}$ & $72.50( \pm 29.50) \mathrm{A}$ \\
\hline \multicolumn{5}{|c|}{ SWC (\%) } \\
\hline $0-10 \mathrm{~cm}$ & $21.47( \pm 3.01) \mathrm{a}$ & $21.80( \pm 3.41) \mathrm{a}$ & $25.86( \pm 4.48) \mathrm{a}$ & $45.56( \pm 16.51) \mathrm{a}$ \\
\hline $10-20 \mathrm{~cm}$ & $21.77( \pm 4.22) \mathrm{a}$ & $23.12( \pm 2.52) \mathrm{a}$ & $25.86( \pm 4.48) \mathrm{a}$ & $40.12( \pm 13.52) b$ \\
\hline $20-40 \mathrm{~cm}$ & $21.38( \pm 5.27) \mathrm{a}$ & $23.25( \pm 3.12) \mathrm{a}$ & $27.30( \pm 3.15) \mathrm{a}$ & $37.18( \pm 12.91 \mathrm{bc}$ \\
\hline $40-60 \mathrm{~cm}$ & $19.48( \pm 6.15) \mathrm{a}$ & $21.56( \pm 4.87) \mathrm{a}$ & $27.67( \pm 3.95) \mathrm{a}$ & $31.12( \pm 12.13) \mathrm{d}$ \\
\hline Average & $21.03( \pm 4.81) \mathrm{C}$ & $22.34( \pm 3.47) \mathrm{C}$ & $26.68( \pm 3.90) \mathrm{B}$ & $37.52( \pm 13.41) \mathrm{A}$ \\
\hline \multicolumn{5}{|c|}{$\operatorname{SBD}\left(\mathrm{g} / \mathrm{cm}^{3}\right)$} \\
\hline $0-10 \mathrm{~cm}$ & $1.12( \pm 0.11) \mathrm{a}$ & $1.04( \pm 0.08) \mathrm{a}$ & $0.91( \pm 0.14) \mathrm{a}$ & $0.65( \pm 0.15) d$ \\
\hline $10-20 \mathrm{~cm}$ & $1.14( \pm 0.14) \mathrm{a}$ & $1.01( \pm 0.08) \mathrm{a}$ & $0.94( \pm 0.11) \mathrm{a}$ & $0.76( \pm 0.15) b c$ \\
\hline $20-40 \mathrm{~cm}$ & $1.14( \pm 0.17) \mathrm{a}$ & $1.01( \pm 0.09) \mathrm{a}$ & $0.92( \pm 0.07) \mathrm{a}$ & $0.81( \pm 0.19 b$ \\
\hline $40-60 \mathrm{~cm}$ & $1.17( \pm 0.18) \mathrm{a}$ & $1.04( \pm 0.14) \mathrm{a}$ & $0.93( \pm 0.10) \mathrm{a}$ & $0.95( \pm 0.25) \mathrm{a}$ \\
\hline Average & $1.14( \pm 0.15) \mathrm{A}$ & $1.03( \pm 0.10) \mathrm{B}$ & $0.93( \pm 0.11) \mathrm{C}$ & $0.80( \pm 0.22) \mathrm{D}$ \\
\hline
\end{tabular}

SF: south-facing slope, SW: southwest slope, NW: northwest slope, NF: north-facing slope, SDT: soil daily temperature, SOC: soil organic carbon, SWC: soil water content, SBD: soil bulk density. The different letters show differences at $\mathrm{p}<0.05$ level. Capital letters mean the differences among slope aspect, while lowercase letters mean the differences among soil layers.

to relative abundance (Table 2). On NF, one tree species (Picea crassifolia) was found in the surveyed plots. Canopy density of $P$. crassifolia was $48.35( \pm 1.54) \%$, the number of living trees was $48.58( \pm 2.65)$ per $100 \mathrm{~m}^{2}$, and the number of felled trees was $5.37( \pm 0.94)$ per $100 \mathrm{~m}^{2}$. The height was $14.93( \pm 1.86) \mathrm{m}$, the diameter at breast height was $13.75( \pm 4.11) \mathrm{cm}$, and the canopy cover was $3.58( \pm 1.67) \mathrm{m}^{2}$.

According to Jaccard [63], if CS varies from 0 to 0.25 , then the communities are extremely dissimilar. If it varies from 0.25 to 0.50 , then the communities are moderately dissimilar, and if it varies from 0.50 to 0.75 and from 0.75 to 1.00 , they become moderately similar and extremely similar. CS between NF and other aspects was less than 0.50 , suggesting that it was moderately dissimilar to others, and CS among SF, SW, and NW ranged from 0.50 to 0.75 , meaning that these aspects have a moderately similar plant composition (Table 3). Agropyron cristatum was a common species on all four aspects, but its $\mathrm{I}_{i v}$ decreased from SF to NF. Stipa grandis, Potentilla bifurca, Carex aridula, Oxytropis, Poa pratensis, Carex crebra, and Heteropappus were the common species of SF, SW, and NW. On SF the dominated herbaceous plants were grasses, while in other aspects they were sedges. 
Table 2. Importance values of herbaceous plant species on four slope aspects.

\begin{tabular}{|c|c|c|c|}
\hline $\begin{array}{l}\text { Slope } \\
\text { aspect }\end{array}$ & Species & $I_{i v} \geq 2$ & $\begin{array}{c}\text { Relative } \\
\text { abundance } \\
(\%)\end{array}$ \\
\hline \multirow{20}{*}{ SF } & Agropyron cristatum (G) & 11.97 & 18.40 \\
\hline & Stipa grandis $(\mathrm{G})$ & 6.21 & 4.14 \\
\hline & Potentilla bifurca $(\mathrm{R})$ & 5.79 & 6.83 \\
\hline & Potentilla anserine $(\mathrm{R})$ & 5.67 & 5.98 \\
\hline & Carex aridula $(\mathrm{S})$ & 5.49 & 9.35 \\
\hline & Kobresia capillifolia $(\mathrm{S})$ & 5.44 & 8.50 \\
\hline & Artemisia mongolica $(\mathrm{C})$ & 4.77 & 4.07 \\
\hline & Oxytropis $(\mathrm{L})$ & 4.22 & 2.56 \\
\hline & Poa pratensis $(\mathrm{G})$ & 3.75 & 1.93 \\
\hline & Carex crebra $(\mathrm{S})$ & 3.62 & 4.29 \\
\hline & Achnatherum splendens $(\mathrm{G})$ & 3.58 & 3.52 \\
\hline & Potentilla anserine (C) & 3.22 & 1.37 \\
\hline & Heteropappus (C) & 3.07 & 2.29 \\
\hline & Artemisia vulgairs (C) & 2.94 & 2.90 \\
\hline & Echinochloa crusgalli $(\mathrm{G})$ & 2.89 & 2.33 \\
\hline & Stellera chamaejasme $(\mathrm{T})$ & 2.56 & 0.83 \\
\hline & Anemone rivularis $\left(\mathrm{R}^{+}\right)$ & 2.54 & 2.39 \\
\hline & Iris lactea $(\mathrm{I})$ & 2.19 & 0.51 \\
\hline & Roegneria kamoji (G) & 2.09 & 0.51 \\
\hline & Potentilla multifida $(\mathrm{R})$ & 2.07 & 1.54 \\
\hline \multirow{21}{*}{ SW } & Carex aridula $(\mathrm{S})$ & 8.38 & 14.23 \\
\hline & Agropyron cristatum $(\mathrm{G})$ & 6.26 & 7.39 \\
\hline & Potentilla bifurca $(\mathrm{R})$ & 5.19 & 6.05 \\
\hline & Poa pratensis $(\mathrm{G})$ & 4.64 & 3.67 \\
\hline & Artemisia mongolica $(\mathrm{C})$ & 4.59 & 5.35 \\
\hline & Potentilla multifida $(\mathrm{R})$ & 4.23 & 2.90 \\
\hline & Potentilla anserine (R) & 3.98 & 3.62 \\
\hline & Heteropappus $(\mathrm{C})$ & 3.96 & 3.88 \\
\hline & Kobresia capillifolia $(\mathrm{S})$ & 3.82 & 4.43 \\
\hline & Stipa grandis $(\mathrm{G})$ & 3.31 & 2.24 \\
\hline & Achnatherum splendens $(\mathrm{G})$ & 2.90 & 2.70 \\
\hline & Stellera chamaejasme $(\mathrm{T})$ & 2.89 & 0.91 \\
\hline & Carex crebra $(\mathrm{S})$ & 2.83 & 3.21 \\
\hline & Echinochloa crusgalli $(\mathrm{G})$ & 2.82 & 4.33 \\
\hline & Ligularia virgaurea $(\mathrm{C})$ & 2.76 & 4.05 \\
\hline & Potentilla tanacetifolia $(\mathrm{R})$ & 2.65 & 2.43 \\
\hline & Anaphalis $(\mathrm{C})$ & 2.46 & 1. 91 \\
\hline & Oxytropis (L) & 2.27 & 1.43 \\
\hline & Artemisia vulgairs (C) & 2.23 & 1.82 \\
\hline & Potentilla anserine $(\mathrm{R})$ & 2.06 & 1.14 \\
\hline & Saussurea $(\mathrm{C})$ & 2.05 & 2.25 \\
\hline
\end{tabular}

This study provides basic information related to the combination of hydro-thermal soil characteristics and plant community structure for different slope aspects. According to our results, we found that each slope has a particular hydro-thermal and soil combination (Table 1), and different vegetation composition (Tables 2 and 3), suggesting that slope aspect influences insolation, which affects soil moisture and temperatures regimes in ways that can directly influence the development of vegetation [34-35]. As Van de Water [64] noted, vegetation properties in semi-arid regions depend on both moisture availability and heat load. The abiotic conditions on NW and NF were relatively better than other slope aspects due to low insolation and evaporation $[35,45]$. Except for $\mathrm{pH}$, changes of soil characteristics with soil depth were similar

\begin{tabular}{|c|c|c|c|}
\hline NW & $\begin{array}{c}\text { Kobresia humilis }(\mathrm{S}) \\
\text { Carex crebra }(\mathrm{S}) \\
\text { Agropyron cristatum }(\mathrm{G}) \\
\text { Potentilla bifurca }(\mathrm{R}) \\
\text { Kobresia capillifolia }(\mathrm{S}) \\
\text { Potentilla tanacetifolia }(\mathrm{R}) \\
\text { Stellera chamaejasme }(\mathrm{T}) \\
\text { Anaphalis }(\mathrm{C}) \\
\text { Leontopodium }(\mathrm{C}) \\
\text { Echinochloa crusgalli }(\mathrm{G}) \\
\text { Medicago ruthenica }(\mathrm{L}) \\
\text { Heteropappus }(\mathrm{C}) \\
\text { Stipa grandis }(\mathrm{G}) \\
\text { Poa pratensis }(\mathrm{G}) \\
\text { Carex aridula }(\mathrm{S}) \\
\text { Oxytropis }(\mathrm{L}) \\
\text { Gentiana }\left(\mathrm{G}^{+}\right)\end{array}$ & $\begin{array}{l}20.34 \\
7.46 \\
5.66 \\
3.63 \\
3.51 \\
3.43 \\
3.42 \\
3.27 \\
3.26 \\
3.16 \\
2.76 \\
2.65 \\
2.59 \\
2.58 \\
2.25 \\
2.02 \\
2.00\end{array}$ & $\begin{array}{l}23.89 \\
10.13 \\
7.29 \\
3.50 \\
4.09 \\
2.74 \\
1.74 \\
3.96 \\
4.70 \\
3.90 \\
2.10 \\
2.81 \\
1.47 \\
1.74 \\
3.76 \\
0.79 \\
0.99\end{array}$ \\
\hline $\mathrm{NF}$ & $\begin{array}{c}\text { Carex spp. }(\mathrm{S}) \\
\text { Polygonum macrophyllum }(\mathrm{P}) \\
\text { Fragaria ananassa }(\mathrm{R}) \\
\text { Pedicularis }\left(\mathrm{S}^{+}\right) \\
\text {Agropyron cristatum }(\mathrm{G}) \\
\text { Polygonatum sibiricum }\left(\mathrm{L}^{+}\right) \\
\text {Thalictrum baicalense }\left(\mathrm{R}^{+}\right) \\
\text {Potentilla tanacetifolia }(\mathrm{R}) \\
\text { Oxytropis }(\mathrm{L})\end{array}$ & $\begin{array}{l}27.94 \\
12.70 \\
11.03 \\
5.38 \\
5.05 \\
4.37 \\
3.67 \\
2.92 \\
2.21\end{array}$ & $\begin{array}{c}38.16 \\
3.54 \\
14.06 \\
1.56 \\
7.93 \\
5.93 \\
2.12 \\
2.28 \\
0.80\end{array}$ \\
\hline
\end{tabular}

SF: south-facing slope, SW: southwest slope, NW: northwest slope, NF: north-facing slope, G: Grass, S: Sedge, R: Rosaceae, $\mathrm{C}$ : Compositae, $\mathrm{T}$ : Thymelaeaceae, $\mathrm{R}^{+}$: Ranunculaceae, I: Iridaceae, L: Legume, and $\mathrm{L}^{+}$: Liliaceae.

to others $[40,65]$. In most studies, they found that $\mathrm{pH}$ decreased with soil depth [66], but this was not the case in this study. $\mathrm{pH}$ of the top layer was significantly lower than other layers on each slope aspect, this may be caused by higher evaporation. In recent years, due to global warming and higher evaporation, $\mathrm{pH}$ on all slope aspects increased in recent years, especially on SF, and higher evaporation may be a direction of water movement in the soil profile, resulting in soluble salts in the groundwater moving upward and accumulating in topsoil [67]. Under harsh environments on SF and SW, plants have the capability to survive, suggesting that these species display a higher resistance toward problematic areas [6].

Table 3. Community similarity among slope aspects.

\begin{tabular}{|c|c|c|c|c|}
\hline & SF & SW & NW & NF \\
\hline SF & 1 & 0.73 & 0.68 & 0.46 \\
\hline SW & & 1 & 0.69 & 0.48 \\
\hline NW & & & 1 & 0.48 \\
\hline NF & & & & 1 \\
\hline
\end{tabular}

SF: south-facing slope, SW: southwest slope, NW: northwest slope, NF: north-facing slope 
Restoration of degraded areas of the Qilian Mountains should be a two-step process. First, plant composition and the restoration measures for each slope should be confirmed, and second the successes of the planned measures should be established by long-term monitoring, especially for vegetation cover and composition, because they are two of the most commonly used as groups of monitoring indicators, and used to evaluate land recovery and the success of restoration projects in many terrestrial ecosystems [68]. Based on Table 2, the restoration project should use herbaceous plants on SF, SW, and NW. In practice, seeds could be collected from plants with $\mathrm{I}_{i v}>2$, and then mixed species sowing based on relative abundance and plant-specific $\mathrm{I}_{i v}$ in the community. Mixed vegetation species will respond better (in terms of survival/growth rates and high diversity) to different methods of planting, climatic factors, weed invasion, and water table depth [52, 59]. Although CS among SF, SW, and NW was moderately similar, the dominated plant species were different, suggesting that restoration should combine CS and $\mathrm{I}_{i v}$ to determine target plant composition. The survey suggests that land will have lower soil water content and greater soil temperature compared with less degraded land so that short-term irrigation might be useful if it can be implemented to infiltrate at least $60 \mathrm{~cm}$ into the soil, because irrigation can increase long-term grass establishment and reduce erosion [23], and diffuse salinity. Although Szitár et al. [69] found that altered soil conditions are unlikely to pose a major limitation to vegetation recovery and restoration measures do not need to bother with soil remediation, the high mean $\mathrm{pH}$ value $(>8)$ may have affected plant survival [52] because it leads to a reduced availability of micronutrients that are important for plant growth [46]. On NF, trees $(P$. crassifolia) should be planted because forest plantations aiming at restoration could increase plant growth and carbon sequestration [70-71]. However, soil daily temperature will be greater on a degraded mountain due to lack of shade, so seedling establishment of $P$. crassifolia may be inhibited by soil temperature. In this case, artificial cultivation of $P$. crassifolia is needed to overcome critical seeding establishment and to increase survival rates $[52,72-73]$. After the plants reach a certain height and are able to shade each other, they can be transplanted onto degraded land with a canopy density of about $48 \%$. However, the opening of vegetation as a result of harvesting timber could create favorable habitats for the invasion of xeromorphic species [74]. To increase biodiversity, felling more than five trees per $100 \mathrm{~m}^{2}$ or decreasing canopy density to $<48 \%$ might work, but soil water content on NF suggests that much water is needed to support such vegetation.

Society should participate in all phases of restoration programs, as they provide excellent opportunities to improve human welfare, and this objective may be achieved by encouraging participatory management and integrating restoration actions into land planning, development programs, and a larger temporal framework of ecological processes [2, 17, 75-76]. For example, the
Qilian Mountains are the water source of the upper Heihe, and its recovery must benefit the middle- and down-stream users, especially for Inner Mongolia because its Populus euphratica forest are supported by the Heihe. Therefore, ecological compensation in the form of work or funding (e.g., Cao [48]) may be needed during the restoration process to avoid livestock trampling of newly restored landscapes, because the greatest challenge to restoration is often lack of social capital and supportive institutions to initiate and sustain restoration efforts [77], but how to gain social capital and to establish these supportive institutions needs further study in this area. Restoration is a long-term process of ecosystem recovery [27]; therefore, every two or three years the restored plant communities should be monitored, and in some cases remedial action taken. The monitoring over longer scales is an essential component that will result in improved success and efficiency of future revegetation programs, and the lack of a suitable followup strategy may undermine the efforts made, and quickly bring the system back to its initial degraded conditions [78-79]. A successful outcome would be a community that is like the original plant community for each slope aspect from the baseline survey.

This study focused only on recovery of the upper slope (2,900 $\mathrm{m})$ of the degraded mountains in Da Yekou Basin, so its application is very limited and the mechanism of interaction between abiotic factors and biotic factors is not discussed in depth. Plant community composition is not only affected by slope aspect, but also by slope gradient, slope position, and elevation, so in order to achieve greater success of recovery, more plant community composition studies related to these factors are needed to inform ecological restoration [22] before restoration work begins. However, the methods to select and restore native plants can be widely used across the Qianlian Mountains.

\section{Conclusions}

In this study we found that each slope aspect has a unique abiotic conditon and plant community composition, and along a south to north-facing slope gradient, the vegetation composition gradually changes as trees become more dominant. On SF, SW, and NW, herbaceous plant species were dominant, while on NF, tree species were dominant. Although SF, SW, and NW have moderately similar plant compositions, the dominant species were different among them, with grasses dominating SF, and sedges dominating the other two slope aspects.

The baseline survey points to the need to consider underlying patterns in abiotic conditions when planning restoration programs in these degraded mountain habitats, and to focus on (i) the selection of native plants (or similar) to the original vegetation when designing interventions and (ii) using baseline community structures to gauge progress and set targets for restoration programs. Furthermore, this survey provides a vital milestone for the development of policy-based funding 
initiatives and for ongoing vegetation monitoring during restoration to assess whether vegetative targets have been met.

\section{Acknowledgements}

This study was supported by the Natural Sciences Foundation of China (Nos. 31370466 and 31270482). We are grateful to all the staff of Xishui Ecological Station for their help in the investigation, and to Dr. Zhang Shiting for help in writing the manuscript.

\section{References}

1. DESCHEEMAEKER K., NYSSEN J., POESEN J., RAES D., HAILE M., MUYS B. Runoff on slopes with restoring vegetation: A case study from the Tigray highlands, Ethiopia. J Hydrol., 331 (1-2), 219, 2006.

2. WALKER L.R., WARDLE D.A. Plant succession as an integrator of contrasting ecological time scales. Trends Ecol. Evol., 29 (9), 504, 2014.

3. ZHAO C., NAN Z., CHENG G. Methods for modelling of temporal and spatial distribution of air temperature at landscape scale in the southern Qilian mountains, China. Ecol. Model., 189 (1-2), 209, 2005.

4. KANG E., LU L., XU Z. Vegetation and carbon sequestration and their relation to water resources in an inland river basin of Northwest China. J Environ.Manage., 85 (3), 702, 2007.

5. ZOU M., ZHU K.H., YIN J.Z., BIN G.U. Analysis on Slope Revegetation Diversity in Different Habitats. Procedia Earth and Planetary Science., 5 (8), 180, 2012.

6. AIMME H.N., NORMANIZA O. The effects of plant density of Melastoma malabathricum on the erosion rate of slope soil at different slope orientations. Int. J. Sediment. Res., 30 (2), 131,2015.

7. JIN B.W., KANG E.S., SONG K.C., LIU X.D. Ecohydrological Function of Mountain Vegetation in the Hei River Basin, Northwest China. J.Glaciology Geocryolo., 25 (5), 580, 2003.

8. ZHAO W.J., LIU X.D., JIN M., CHE Z.X., YU M.A. Study on Soil Nutrient Characteristics of Picea crassifolia Forest in the West Segment of Qilian Mountains. J. Soil. Water. Conserv., 18 (4), 166, 2011.

9. WAGNER B., LIANG E., LI X., DULAMSUREN C, LEUSCHNER C, HAUCK M. Carbon pools of semi-arid Picea crassifolia forests in the Qilian Mountains (northeastern Tibetan Plateau). Forest. Ecol. Manag., 343, 136, 2015.

10. HOUGHTON R.A. Tropical deforestation and atmospheric carbon dioxide. Clima. Chan., 19, 1-2, 99, 1991.

11. DEYN G.B.D., CORNELISSEN J.H.C., BARDGETT R.D. Plant functional traits and soil carbon sequestration in contrasting biomes. Ecol. Lett., 11 (5), 516, 2008.

12. GUO L.B., GIFFORD R.M. Soil carbon stocks and land use change: a meta analysis. Global Change Bio., 8, 345, 2002.

13. KING G.M. Enhancing soil carbon storage for carbon remediation: potential contributions and constraints by microbes. Trends in Microbio., 19 (2), 75, 2011.

14. PETE F., JONES C.D., MELANIE A., KERYN P. Direct soil moisture controls of future global soil carbon changes: An important source of uncertainty. Global Biogeochemical Cy., 25 (3), 263, 2011.
15. MORA J.L., ARMAS-HERRERA C.M., GUERRA J.A., RODRIGUEZ-RODRIGUEZ A., ARBELO C.D. Factors affecting vegetation and soil recovery in the Mediterranean woodland of the Canary Islands (Spain). J. Arid. Environ., 87 (87), 58, 2012.

16. WESTWOOD A., REUCHLIN-HUGENHOLTZ E., KEITH D.M. Re-defining recovery: A generalized framework for assessing species recovery. Biol.Conser., 172 (172), 155, 2014.

17. CORTINA J., AMAT B., CASTILLO V., FUENTES D., MAESTRE F.T., PADILLA F.M. The restoration of vegetation cover in the semi-arid Iberian southeast. J. Arid. Environ., 75 (12), 1377, 2011.

18. FUENTE C.D.L., PARDO T., ALBURQUERQUE J.A., MARTINEZ-AICALA I., BERNAL M.P., CLEMENTE R. Assessment of native shrubs for stabilisation of a trace elements-polluted soil as the final phase of a restoration process. Agr. Ecosyst. Environ., 196, 103, 2014.

19. ABELLA S.R., CHIQUOINE L.P., NEWTON A.C., VANIER C.H. Restoring a desert ecosystem using soil salvage, revegetation, and irrigation. J. Arid. Environ., 115, 44, 2015.

20. LIN W.T., CHOU W.C., LIN C.Y., HUANG P.H., TSAI J.S. Vegetation recovery monitoring and assessment at landslides caused by earthquake in Central Taiwan. Forest. Ecol. Manag., 210 (1), 55, 2005.

21. SCOTTA.J., MORGAN J.W. Recovery of soil and vegetation in semi-arid Australian old fields. J. Arid. Environ.,76 (1), 61, 2012.

22. BIBLE J.M., SANFORD E. Local adaptation in an estuarine foundation species: Implications for restoration. Biol. Conserv., 193, 95, 2016.

23. PORENSKY L.M., LEGER E.A., DAVISON J., MILLER W.W., GOERGEN E.M., ESPELAND E.K. Arid old-field restoration: Native perennial grasses suppress weeds and erosion, but also suppress native shrubs. Agr. Ecosyst. Environ., 184 (1), 135, 2014.

24. HELMAN D., LENSKY I.M., MUSSERY A., LEU S. Rehabilitating degraded drylands by creating woodland islets: Assessing long-term effects on aboveground productivity and soil fertility. Agr. Ecosyst. Environ., 195-196, 52, 2014.

25. WU H., LI X.Y., JIANG Z., CHEN H., ZHANG C., XIAO $X$. Contrasting water use pattern of introduced and native plants in an alpine desert ecosystem, Northeast Qinghai Tibet Plateau, China. Sci.Total. Environ., 542 (PT-A), 182, 2016.

26. RYDGREN K., HALVORSEN R., ODLAND A., SKJERDAL G. Restoration of alpine spoil heaps: Successional rates predict vegetation recovery in 50 years. Ecol. Engin., 37 (2), 294, 2011.

27. LORITE J., MOLINA-MORALES M., CANADAS E.M., BALLESTEROS M, PENAS J. Evaluating a vegetationrecovery plan in Mediterranean alpine ski slopes: A chronosequence-based study in Sierra Nevada (SE Spain). Landscape. Ecol., 97 (2), 92, 2010.

28. PUEYO Y., ALADOS C.L. Effects of fragmentation, abiotic factors and land use on vegetation recovery in a semi-arid Mediterranean area. Basic Appl.Ecol., 8 (2), 158, 2007.

29. RAZANAAJATOVO M., FOHR C., FISCHER M., PRSTI D., KLEUNEN M.V. Non-naturalized alien plants receive fewer flower visits than naturalized and native plants in a Swiss botanical garden. Biol. Conserv., 182 (182), 109, 2015.

30. MOREIRA-ARCE D, VERGARA P.M., BOUTIN S., CARRASCO G., BRIONES R., SOTO G.E. Mesocarnivores respond to fine-grain habitat structure in a mosaic landscape 
comprised by commercial forest plantations in Southern Chile. Forest. Ecol. Manag., 369, 135, 2016.

31. CREES J.J., TURVEY S.T. What constitutes a 'native' species? Insights from the Quaternary faunal record. Biol. Conserv., 186, 143, 2015.

32. BALE C.L., WILLIAMS J.B., CHARLEY J.L. The impact of aspect on forest structure and floristics in some Eastern Australian sites. Forest. Ecol. Manag., 110 (1-3), 363, 1998.

33. SHARM C.M., BADUNI N.P., GAIROLA S., GHILDIYAL S.K., SUYAL S. Effects of slope aspects on forest compositions, community structures and soil properties in natural temperate forests of Garhwal Himalaya. Ecol. Res., 21 (3), 331, 2010.

34. DAHLGREN M., LAGERKVIST C.I., FITZSIMMONS A., WILLIAMS I.P., GORDON M. A study of Hilda asteroids. II. Compositional implications from optical spectroscopy. Astron. Astrophy., 323 (2), 606, 1997.

35. LOZANO-GARCIA B., PARRAS-ALCANTARA L., BREVIK E.C. Impact of topographic aspect and vegetation (native and reforested areas) on soil organic carbon and nitrogen budgets in Mediterranean natural areas.Sci Total Environ., 544 (8), 963, 2015.

36. KAKEMBO V., ROWNTREE K., PALMER A.R. Topographic controls on the invasion of Pteronia incana (Blue bush) onto hillslopes in Ngqushwa (formerly Peddie) district, Eastern Cape, South Africa. Catena., 70 (2), 185, 2007.

37. STERNBERG S. Separate modifiability, mental modules, and the use of pure and composite measures to reveal them. Acta Psychologica., 106, (1-2),147, 2001.

38. BADANO E.I., CAVIERES L.A., MOLINAMONTENEGRO M.A., QUIROZ C.L. Slope aspect influences plant association patterns in the Mediterranean matorral of central Chile. J. Arid. Environ., 62 (1), 93, 2005.

39. BELLO F.D., LEP J., SEBASTIA M.T. Variations in species and functional plant diversity along climatic and grazing gradients. Ecography., 29 (6), 801, 2006.

40. GONG X., BRUECK H., GIESE K.M., ZHANG L., SATTELMACHER B, LIN S. Slope aspect has effects on productivity and species composition of hilly grassland in the Xilin River Basin, Inner Mongolia, China. J. Arid. Environ., 72 (4), 483, 2008.

41. LI X., NIE Y., SONG X., ZHANG R., WANG G. Patterns of species diversity and functional diversity along the southto north-facing slope gradient in a sub-alpine meadow. Community. Eco., 12 (2), 179, 2011.

42. WANG C., ZHAO C.Y., XU Z.L., WANG Y., PENG H.H. Effect of vegetation on soil water retention and storage in a semi-arid alpine forest catchment. J.Arid. Land., 5 (2), 207, 2013.

43. LEONELLI G., PELFINI M., BATTIPAGLIA G., CHERUBINI P. Site-aspect influence on climate sensitivity over time of a high-altitude Pinus cembra tree-ring network. Clim.Chan., 96, (1-2), 185, 2009.

44. ORTIZ-PULIDO R., PAVON N.P. Influence of slope orientation on sex ratio and size distribution in a dioecious plant Bursera fagaroides var. purpusii (Brandeg.) McVaugh and Rzed. (Burseraceae). Plant Ecol., 208 (2), 271, 2010.

45. BEULLENS J., VELDE D.V.D., NYSSEN J. Impact of slope aspect on hydrological rainfall and on the magnitude of rill erosion in Belgium and northern France. Catena., 114 (2), 129, 2014

46. MAREN I.E., KARKI S., PRAJAPATI C., YADAV R.K., SHRESTHA B.B. Facing north or south: Does slope aspect impact forest stand characteristics and soil properties in a semiarid trans-Himalayan valley? J. Arid. Environ., 121, 112, 2015.
47. WEN L., DONG S., ZHU L., LI X., SHI J., WANG Y. The construction of grassland degradation index for alpine meadow in Qinghai-Tibetan plateau. Procedia Environ. Sci., 2 (6), 1966, 2010

48. CAO J.J., HOLDEN N. M., QIN Y.Y. Using WTA to Estimate the Ecological Compensation of the Grassland. Rang. Ecol. Manage., 65, 533, 2012.

49. LOUHAICHI M., GHASSALI F., SALKINI A.K., PETERSEN S.L. Effect of sheep grazing on rangeland plant communities: Case study of landscape depressions within Syrian arid steppes. J. Arid. Environ., 79 (79), 101, 2012.

50. MCLOUGHLIN L. The Impact of Planting for Restoration of Remnant Bushland on Its Scientific and Educational Values: Implications for Conservation Planning. Pacific Conser. Biol., 3 (1), 5, 1997.

51. HOBBS R.J., ARICO S., ARONSON J., BARON J.S., BRIDGEWATER P., CRAMER V.A. Novel ecosystems: theoretical and management aspects of the new ecological world order. Global Ecol. Bio., 15 (1), 1, 2006.

52. WEBB A.A., ERSKINE W.D. A practical scientific approach to riparian vegetation rehabilitation in Australia. J. Environ. Manage., 68 (4), 329, 2003.

53. RODRIGO M.A., ROJO C., ALONSO-GUILLEN J.L., VERA P. Restoration of two small Mediterranean lagoons: The dynamics of submerged macrophytes and factors that affect the success of revegetation. Ecol. Engin., 54 (54), 1, 2013.

54. EVANS D.M., ZIPPER C.E., BURGER J.A., STRAHM B.D., VILLAMAGNA A.M. Reforestation practice for enhancement of ecosystem services on a compacted surface mine: Path toward ecosystem recovery. Ecol. Engin., 51 (1), $16,2013$.

55. ZHAO S., CHENG W., ZHOU C., CHEN X., CHEN J. Simulation of decadal alpine permafrost distributions in the Qilian Mountains over past 50years by using Logistic Regression Model. Cold Regions Science and Technology., 73 (1), 32, 2012.

56. QIN C., BAO Y., BURCHARDT I., HU X., KANG X. Intensified pluvial conditions during the twentieth century in the inland Heihe River Basin in arid northwestern China over the past millennium. Global Planetary Change., 72 (72), 192, 2010.

57. WU J. The effect of ecological management in the upper reaches of Heihe River. Acta Ecol. Sin., 31 (1), 1, 2011.

58. ZHANG P. Study on individual WUE population dynamic and soil carbon-nitroen of Picea crassifolia. Gansu Agricultural University Lanzhou China, 2009 [In Chinese].

59. MARTINEZ-GARZA C., BONGERS F., POORTER L. Are functional traits good predictors of species performance in restoration plantings in tropical abandoned pastures? Forest. Ecol. Manag., 303, 35, 2013.

60. NELSON D., SOMMERS L., Total carbon, organic carbon and organic matter. In DANE J.H.,TOPP G.C. Methods of Soil Analysis, Part 2. Second eds No 9. ASA Publication, Madison. 1982

61. CHAPIN F.S., KEDROWSKI R.A. Seasonal Changes in Nitrogen and Phosphorus Fractions and Autumn Retranslocation in Evergreen and Deciduous Taiga Trees. J.Ecol., 64, 376, 1983.

62. SHANG Z.H., YAO A.X. Studies on biodiversity in the core region of Zhongwei Goat in Ningxia -The Cluster Analysis and Similarity of plant communities. Journal of Ningxia Agricultural College. 23 (1), 23, 2002 [In Chinese].

63. ZHAO Y., PETH S., HALLETT P., WANG X., GIESE M., GAO Y. Factors controlling the spatial patterns of 
soil moisture in a grazed semi-arid steppe investigated by multivariate geostatistics. Ecohydrology., 4 (1), 36, 2011.

64. WATER P.K.V.D., LEAVITT S.W., BETANCOURT J.L. Leaf $\delta^{13} \mathrm{C}$ variability with elevation, slope aspect, and precipitation in the southwest United States. Oecologia., 132 (3), 332, 2002.

65. USSIRI D.A.N., LAL R. Land Management Effects on Carbon Sequestration and Soil Properties in Reclaimed Farmland of Eastern Ohio, USA. Open Journal of Soil Science., 3 (1), 46, 2013.

66. SONMEZ S., MACAR N., DEMIROZER A.İ. The Influence of Aspect on the Vegetation of Çataldağ. Procedia - Social and Behavioral Sciences., 120, 566, 2014.

67. LI X.G., LI Y.K., LI F.M., MA Q.F., ZHANG P.L., YIN P. Changes in soil organic carbon, nutrients and aggregation after conversion of native desert soil into irrigated arable land. Soil Tillage Res., 104 (2), 263, 2009.

68. GODINEZ-ALVAREZ H., HERRICK J.E., MATTOVKS M., TOLEDO D., ZEE J.V. Comparison of three vegetation monitoring methods:Their relative utility for ecological assessment and monitoring. Ecol. Indicat., 9 (5), 1001, 2009.

69. SZITAR K., ÓNODI G., SOMAY L., PANDI I., KUCS P., KROEL-DULAY G. Recovery of inland sand dune grasslands following the removal of alien pine plantation. Biol. Conserv., 171 (171), 52, 2014.

70. FERRETTI A.R., BRITEZ R.M.D. Ecological restoration, carbon sequestration and biodiversity conservation: The experience of the Society for Wildlife Research and Environmental Education (SPVS) in the Atlantic Rain Forest of Southern Brazil. Fluessiges Obst., 129 (3), 467, 1994.

71. FEREZ A.P.C., CAMPOE O.C., MENDES J.C.T., STAPE J.L. Silvicultural opportunities for increasing carbon stock in restoration of Atlantic forests in Brazil. For.Ecol. Manage., 350, 40, 2015.

72. SILES G., REY P.J., ALCANTARA J.M., BASTIDA J.M., HERREROS J.L. Effects of soil enrichment, watering and seedling age on establishment of Mediterranean woody species. Acta Oecologica., 36 (4),357, 2010.

73. FAJARDO L., RODRIGUEZ J.P., GONZALEZ V., BRICENO-LINAES J.M. Restoration of a degraded tropical dry forest in Macanao, Venezuela. J. Arid. Environ., 88 (1), 236, 2013.

74. ARMESTO J.J., MARTINEZ J.A. Relations between vegetation structure and slope aspect in the Mediterranean region of Chile. J. Eco., 66 (3), 1, 1978.

75. REDPATH S.M., YOUNG J., EVELY A., ADAMS W.M., SUTHERLAND W.J., WHITEHOUSE A. Understanding and managing conservation conflicts. Trends Ecol. Evo., 28 (2), 100, 2013

76. YOUNG J.C., JORDAN A., SEARLE K.R., BUTLER A., CHAPMAN D.S., SIMMONS P. Does stakeholder involvement really benefit biodiversity conservation? Biol. Conserv., 158 (2), 359, 2013.

77. STANTURF J.A., PALIK B.J., DUMROESE R.K. Contemporary forest restoration: A review emphasizing function. Forest. Ecol. Manag., 331(331), 292, 2014.

78. ZUCCA C., WU W., DESSENA L., MULAS M. Effects of restoration actions on soil and landscape functions: Atriplex nummularia L. plantations in Ouled Dlim (Central Morocco). Soil. Till. Res., 133 (2013), 101, 2014.

79. HU Z.J., GE Z.M., MA Q., ZHANG Z.T., TANG C.D., CAO H.B. Revegetation of a native species in a newly formed tidal marsh under varying hydrological conditions and planting densities in the Yangtze Estuary. Ecol. Engin., 83, 354, 2015. 
